\title{
Religion and Human Security A Global Perspective
}

\section{Journal Article}

Author(s):

Mason, Simon Jonas Augusto (i)

Publication date:

2014

Permanent link:

https://doi.org/10.3929/ethz-b-000083225

Rights / license:

$\underline{\text { In Copyright - Non-Commercial Use Permitted }}$

Originally published in:

Journal of Church and State 56(2), https://doi.org/10.1093/jcs/csu012 
accommodate those who disclaim any religion? Given the partisan overtones of debates regarding religion and secularism, such a controversy runs the risk of inflaming passions that once unleashed are difficult to contain. Nussbaum's three principles are thus a good way for partisans of both the secular left and religious right to overcome their suspicion-even their fear-of not only Muslims, but one another.

David E. Campbell

University of Notre Dame

Notre Dame, Indiana

doi:10.1093/jcs/csu017

Advance Access publication March 30, 2014

Religion and Human Security: A Global Perspective. Edited by James K. Wellman and Clark B. Lombardi. New York: Oxford University Press, 2012. 321pp. \$35.00.

The book Religion and Human Security is a treasure trove of case studies providing rich insights for policy-makers, practitioners, and scholars alike. The exploration of how religious actors affect human security is refreshing in its breadth and depth and freedom from any narrow theoretical framework. The combination of two concepts, human security and religion, provides a broad analytical framework for the thirteen case studies - mainly focusing on Islamic and Christian actors. The definition of religion ("socially enacted desire for the ultimate" p. 9) fits well with the three dimensions of human security used (physical welfare, human rights, and subjective dimensions). These definitions also allow space for mystery in religion-for example illustrated by popular religiosity in Brazil or the deinstitutionalization movement in Zimbabwe.

The link between religion, identity, and human security comes up in numerous case studies. Beyond being an "identity marker," religion can shape identity and political attitudes as it influences a community's worldviews, interests, fears, and desires. The case study of Northern Ireland using the existential security theory seems to indicate a vicious circle between insecurity leading to greater religiosity (that strengthens identity in the face of threat), which then leads to greater polarization, heightened conflict, greater threat, and heightened religiosity. In this case, increasing secularization seemed to have opened the space for political agreement between the communities. In another context, however, such as in Jequitinhonha Valley in 
Brazil, popular religiosity strengthened the identity and voice of the oppressed, leading to political changes and thereby enhancing human security. Religion can influence identity and this can lead to escalating conflict in one context, and greater political participation and human security in another.

Another thread that runs through the book is the relationship between religious actors and the state in providing (or harming) human security. In this relationship, religious actors can cooperate, complement, substitute, or compete with the state actor in providing human security. Diverse religious communities cooperate with each other and local state authorities in Malerkotla, India, thereby creating an oasis of peace. The Buddhist community Soka Gakkai in Japan is another example of a cooperative relationship with the state actor, which has also helped to maintain Japan's pacifist stance. While a cooperative or complementary relationship between state and religious actors seems best suited to providing human security, both the state and the religious actors may be concerned about infiltration, manipulation, and being co-opted by the other. The concept of symphonia in Orthodox churches in Eastern Europe describes how religious actors sought concord with the political realm during communism. At times this meant a loss of independence, yet it seems to have been central to the survival of the church in the restrictive context in which it found itself.

When religious actors substitute state actors in providing social services, as some of the African case studies indicate, human security may benefit in the short-term, even if this does not necessarily lead to the long-term enhancement of human security that needs political changes. This seems to be one of the main reasons why a cooperative approach of religious actors toward the state seems preferable to a pure substitution approach. In cases where the religious actor was substituting the state in providing human security, for example by providing social services, the relationship can also change to a competitive one, shown for example by the dynamic relationship between the Muslim Brotherhood and the pre-Arab Spring Egyptian government.

A competitive relationship between religious and state actors contains the potential for violence, although this is not predetermined. The comparison of religious opposition to state oppression in Poland and Algeria stresses the importance of the third dimension of human security, that of political subjectivity. As long as the space for expression of dissent is given, nonviolent resistance seems possible, even if the physical welfare and human rights are impinged on (e.g., Poland). If all three dimensions of human security are trampled by the state, however, the likelihood of violent resistance, and counterviolence, seems greater (e.g., Algeria). The balance between a competitive or 
cooperative relationship seems also strongly influenced by the dynamics taking place within a religious community, for example illustrated by the different strains of Muslim communities in India.

Overall, the case studies show how no culture, ideology, or religion can explain variable outcomes because "Religious culture interacts with other variables to influence social action” (p. 261). In-depth analysis of both the state and the religious actors using a case-by-case approach is therefore essential. More research, education, and dialog between political and religious actors are needed to prevent violence and better use the potential of religious actors in enhancing human security.

Simon J. A. Mason

Center for Security Studies, ETH Zurich

Zurich, Switzerland

doi:10.1093/jcs/csu012

Advance Access publication March 26, 2014

Islam in the West: Key Issues in Multiculturalism. Edited by Max Farrar, Simon Robinson, Yasmin Valli, and Paul Wetherley. London \& New York: Palgrave Macmillan, 2012. 272pp. \$100.00.

As Shaykh Ibrahim Mogra so eloquently writes in his foreword to this timely volume, open debates on questions of multiculturalism, integration, and assimilation can "help us to move forward as a diverse but cohesive nation." This statement and the majority of the essays in this book address issues related to being Muslim in the West via specific examples from the British context. Yet the questions of belief, identity, hybridity, diversity, and social cohesion that they raise can be found at the center of social and cultural political agendas not only in the United Kingdom and mainland Europe, but also much farther afield.

Throughout the western world, Muslims in all their diversity find themselves repeatedly constructed in public debates as a homogeneous group whose lifestyles and values are ill-suited to the countries they regard as home by dint of birth or settlement. (Often they share this experience with refugees, asylum seekers, and other minorities who are widely regarded as problems.) The essays in this book take issue with assumptions about homogeneity and incompatibility, stressing both the diversity of Muslims in the West and their complex relations with the wider societies in which they live. 